\title{
Molecular Detection of Enterococcal Surface Protein (esp) Gene in Enterococcus faecalis Isolated from Dental Calculus of Patients in Sari, Iran
}

\author{
Mona Akhondnezhad ${ }^{1}$, Mehrnaz Bakhti ${ }^{1}$, Mohtaram Nasrolahei ${ }^{1}$, Bizhan Shabankhani ${ }^{2}$, Hamid Reza Goli ${ }^{1 *}$ \\ ${ }^{1}$ Department of Microbiology, Faculty of Medicine, Mazandaran University of Medical Sciences, Sari, Iran. \\ ${ }^{2}$ Department of Biostatistics, Health Sciences Research Center, Faculty of Public Health, Mazandaran University of Medical Sciences, Sari, Iran.
}

Received: 15 Jul 2017

Revised : 24 Aug 2017

Accepted: 10 Sep 2017

Corresponding Author:

Hamid Reza Goli

Department of Microbiology, Faculty of Medicine, KM 18 Khazarabad Road, Khazar Sq, Sari, Iran. Phone: +98-1133542067

E-mail: goli59@gmail.com

\begin{abstract}
Background: Enterococci are important gram-positive bacteria causing dental calculus in human beings; however, the role of these bacteria in oral cavity is unclear. The aim of this study was to investigate the presence of Enterococcal Surface Protein (esp) gene in Enterococcus faecalis isolated from dental calculus in the city of Sari, Iran.

Materials and Methods: In the present study, 207 dental calculus samples were collected from patients. The isolates were identified by growth on Bile Esculin agar, Gram stain, Catalase test, Growth at $6.5 \% \mathrm{NaCl}$, PYR and arabinose fermentation test. Antimicrobial susceptibility pattern of the isolates was determined by disk agar diffusion method. The presence of $e s p$ gene was assessed by polymerase chain reaction (PCR).

Results: Among the 56 (27\%) enterococci isolated from dental calculus, 43 (76.7\%) were determined as E. faecalis. The resistance rate to ampicillin, vancomycin, tetracycline, ciprofloxacin and erythromycin in E. faecalis isolates was estimated as $13.9 \%, 4.6 \%, 11.6 \%, 6.9 \%$ and $13.9 \%$, respectively. The esp gene was detected in $18.6 \%$ of E. faecalis isolates. Among the isolates containing esp gene, $33.3 \%, 50 \%, 40 \%, 33.3 \%$ and $33.3 \%$ of them were resistant to ampicillin, vancomycin, tetracycline, ciprofloxacin and erythromycin, respectively.

Conclusion: E. faecalis is an important organism causing dental calculus but the presence of esp gene had no correlation with the resistance to tested antimicrobial agents.
\end{abstract}

Keywords: Enterococcus faecalis; Dental Calculus; esp gene; PCR

Please cite this article as: Akhondnezhad M, Bakhti M, Nasrolahei M, Shabankhani B, Goli HR. Molecular Detection of Enterococcal Surface Protein (esp) Gene in Enterococcus faecalis Isolated from Dental Calculus of Patients in Sari, Iran. Res Mol Med, 2017; 5(3): 21-25

\begin{abstract}
Introduction
Enterococci are gram-positive facultative anaerobic cocci that normally inhabit the gastrointestinal tract of humans and animals $(1,2)$. Moreover, these bacteria are found in other parts of the body such as oral cavity and vagina as well as in water, soil, food, plants and insects $(2,3)$. Enterococcus faecalis and Enterococcus faecium are the most common species causing human infections and frequently have been associated with nosocomial infections throughout the world (4). E. faecalis is not a normal flora of the mouth but has been observed in diseases such as dental caries, periodontitis and tooth root infections (1). Several virulence factors can cause the
\end{abstract}

accumulation of these bacteria and initiation of dental infections $(4,5)$. Enterococcal surface protein (ESP) is one of these virulence factors (2). The esp gene encodes ESP with iterative structure causing bacterial adhesion and biofilm formation. ESP is a high molecular weight superficial protein containing 1873 amino acids, which has N-terminals, central core, and C-terminal regions. The C-terminal domain contains a membrane hydrophobic region. Recently, it has been assumed that the N-terminal of ESP participates in interaction with the host and the central region of this protein has an important role in accumulation of the bacteria and hides the mentioned protein from the 
host immune system $(6,7)$. Biofilm is a layer consisting of a mass of bacteria adhering to each other. This layer is composed of a polymerextracellular matrix that is made by the bacteria (8). For example, Enterococcus form the biofilm in dental root canal which was filled previously (1). Biofilm causes bacterial protection against environmental changes, host immune response and antimicrobial agents, thus prevents the treatment of the infections caused by the biofilm producer bacteria $(6,9)$. About $80 \%$ of the bacterial infections are associated with biofilm production (10). In vivo and in vitro experiments demonstrated that minimum bactericidal concentration (MBC) and minimum inhibitory concentration (MIC) of biofilm-forming bacteria are about 1-1000 times higher than that of Planktonic cells, resulting in limitation in treatment of infections caused by these strains (8). Biofilm causes the bacterial colonization on medical instruments and dental surfaces. This leads to accumulation of other bacteria that produce acid due to the metabolism and initiation of dental calculus $(8,10-12)$. The aim of this study was to determine the prevalence of esp gene in E. faecalis isolated from dental calculus in patients referred to a dental clinic.

\section{Materials and Methods}

Sample collection

This study was conducted on 207 samples collected from non-repeated patients referred to the Mostafavian dental clinic in Sari, Iran. This project was explained to the patients and sampling was carried out with the consent of patients. The samples were taken by sterile swabs from the patients' dental calculus. Then, swabs were placed immediately in Brain hurt infusion (BHI) nutrient broth and transferred to the laboratory.

\section{Microbiological and antimicrobial susceptibility} testing

The samples were cultured on blood agar containing $5 \%$ sheep blood under sterile conditions, and incubated for 24 hours at $37^{\circ} \mathrm{C}$. Morphological comparison with grown colonies of Enterococcus faecalis ATCC 29212 (Pasteur Institute of Iran) as a standard strain was used to confirm the suspected colonies of enterococci. The pure cultures of suspected colonies were sub-cultured on Bile Esculin agar, and incubated for 48 hours at $37^{\circ} \mathrm{C}$. Moreover, Gram stain, catalase test, growth at $6.5 \% \mathrm{NaCl}$ and PYR test were performed for early identification of enterococci (13). In this study, arabinose fermentation test was employed to differentiate $E$. faecalis and E. faecium (14).

The susceptibility pattern of the isolates against ampicillin, vancomycin, tetracycline, ciprofloxacin and erythromycin was determined by disk agar diffusion method according to the clinical and laboratory standards institute (CLSI) guidelines (15). E. faecalis ATCC 29212 was chosen as control strain in the antimicrobial susceptibility testing.

\section{DNA extraction}

Genomic DNA was extracted using a DNA extraction kit (Thermo Scientific, Waltham, Massachusetts, United States) according to the manufacturer's instructions.

Detection of the esp gene

PCR was used to detect the presence of esp gene in $E$. faecalis isolated from dental calculus. The sequences of primers used in the present study are shown in Table 1.

Table 1. The primer sequences used in this study.

\begin{tabular}{ccccc}
\hline Gene & Primer & Primer Sequence (5' $\left.\rightarrow \mathbf{3}^{\prime}\right)$ & Amplicon size(bp) & Reference \\
\hline \multirow{2}{*}{$e s p$} & esp 11 - esp 12 & F: TTG CTA ATG CTA GTC CAC GAC C & \multirow{2}{*}{933} & $(\mathbf{1 6})$ \\
\hline
\end{tabular}

The amount of each primer, DNA and master mix (Amplicon, Denmark) used in this test was equal to $10 \mathrm{pmol}, 300 \mathrm{ng} / \mu \mathrm{l}$ and $8 \mu \mathrm{l}$ respectively, and the final volume of reaction was $15 \mu \mathrm{l}$.

The PCR process was carried out by an Eppendorf AG thermal cycler (Germany) as follows: initial denaturation at $94{ }^{\circ} \mathrm{C}$ for $1 \mathrm{~min}$, followed by 30 cycles of denaturation at $94{ }^{\circ} \mathrm{C}$ for $45 \mathrm{sec}$, annealing at $60{ }^{\circ} \mathrm{C}$ for $60 \mathrm{sec}$, extension at $72{ }^{\circ} \mathrm{C}$ for $60 \mathrm{sec}$ with a final extension at $72{ }^{\circ} \mathrm{C}$ for 5 min.

Distilled water and enterococcus faecalis ATCC 29212 were chosen as esp negative and positive control, respectively.

\section{Electrophoresis}

The PCR products along with a $100 \mathrm{bp}$ DNA Ladder and DNA of esp positive control were electrophoresed on 2\% agarose gel (Figure 1). The results were observed with gel documentation device (Vilber lourmat, France), after staining with safe stain (Aryatous, Iran).

\section{Statistical analysis}

Data were analyzed using Statistical Package for Social Science (SPSS, version 22) software. The binomial test was used for analysis of the data and $P$ value $<0.05$ was statistically significant. 


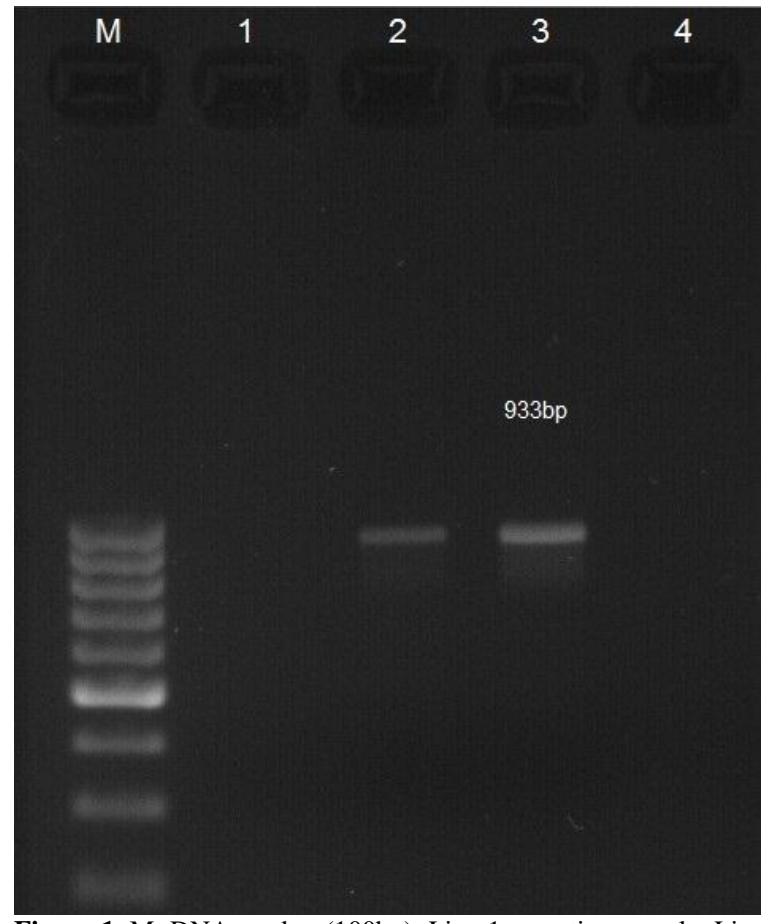

Figure 1. M: DNA marker (100bp); Line 1: negative sample; Line 2: positive sample; Line 3: positive control; Line 4: negative control.

\section{Results}

According to the standard microbiologic tests (13), $56(27 \%)$ of dental calculus isolates were identified as Entrococci. Among these isolates, 43 (76.7\%) of them were confirmed as enterococcus faecalis and others were identified as enterococcus faecium. In this study, $13.9 \%, 4.6 \%, 11.6 \%, 6.9 \%$, and $13.9 \%$ of the isolates were resistance phenotypes against ampicillin, vancomycine, tetracycline, ciprofloxacin and erythromycin, respectively. The molecular assay showed that $8(18.6 \%)$ enterococcus faecalis isolates were esp positive. Interestingly, none of these patients used toothbrush and one patient had denture. There was no significant correlation between the presence of esp gene and the sex of the patients $(P>$ 0.05). Also, the presence of this gene had no significant correlation with the resistance rate against ampicillin, vancomycin, tetracycline, ciprofloxacin and erythromycin (Table 2).

The association between the isolation of enterococcus faecalis and some problems which are related to the patients is shown in Table 3 .

\section{Discussion}

The present study showed that E. faecalis was more prevalent than E. faecium in the samples collected from dental calculus. There was no significant relationship between the variables of questionnaire in patients and E. faecalis prevalence rate. However, there was an important correlation between antibiotic usage and the prevalence of E. faecalis ( $P$-value < $0.01)$.

$\underline{\text { Table 2. Antimicrobial susceptibility results and its correlation with the presence of esp gene in enterococcus faecalis isolates. }}$

\begin{tabular}{|c|c|c|c|c|c|}
\hline Antibiotics & & $\begin{array}{c}\text { Susceptibility pattern of the all } \\
\text { isolates } \\
\text { No. }(\%) \\
\end{array}$ & $\begin{array}{l}\text { No. }(\%) \text { of positive } \\
\text { isolates }\end{array}$ & $\begin{array}{l}\text { No. }(\%) \text { of negative } \\
\text { isolates }\end{array}$ & $P$-value \\
\hline \multirow{3}{*}{ Ampicillin } & $\mathrm{R}$ & $6(13.9 \%)$ & $2(33.3 \%)$ & $4(66.6 \%)$ & \multirow[t]{3}{*}{$P>0.05$} \\
\hline & I & $37(8604 \%)$ & $\begin{array}{c}- \\
6(162 \%)\end{array}$ & $\begin{array}{c}- \\
31(837 \%)\end{array}$ & \\
\hline & S & & & & \\
\hline \multirow{3}{*}{ Vancomycin } & $\mathrm{R}$ & $2(4.6 \%)$ & $1(50 \%)$ & $1(50 \%)$ & \multirow[t]{3}{*}{$P>0.05$} \\
\hline & I & $13(30.2 \%)$ & $2(15.3 \%)$ & $11(84.6 \%)$ & \\
\hline & $S$ & $28(65.1 \%)$ & $5(17.8 \%)$ & $23(82.1 \%)$ & \\
\hline \multirow{3}{*}{ Tetracycline } & $\mathrm{R}$ & $5(11.6 \%)$ & $2(40 \%)$ & $3(60 \%)$ & \multirow{3}{*}{$P>0.05$} \\
\hline & I & $3(6.9 \%)$ & $1(33.3 \%)$ & $2(66.6 \%)$ & \\
\hline & S & $35(81.3 \%)$ & $5(14.2 \%)$ & $30(85.7 \%)$ & \\
\hline \multirow{3}{*}{ Ciprofloxacin } & $\mathrm{R}$ & $3(6.9 \%)$ & $1(33.3 \%)$ & $2(66.6 \%)$ & \multirow{3}{*}{$P>0.05$} \\
\hline & I & $8(18.6 \%)$ & $2(25 \%)$ & $6(75 \%)$ & \\
\hline & S & $32(74.4 \%)$ & $5(15.6 \%)$ & $27(84.3 \%)$ & \\
\hline \multirow{3}{*}{ Erythromycin } & $\mathrm{R}$ & $6(13.9 \%)$ & $2(33.3 \%)$ & $4(66.6 \%)$ & \multirow{3}{*}{$P>0.05$} \\
\hline & I & $1(2.3 \%)$ & - & $1(100 \%)$ & \\
\hline & $\mathrm{S}$ & $36(83.7 \%)$ & $6(16.6 \%)$ & $30(83.3 \%)$ & \\
\hline
\end{tabular}

Abbreviations: R, resistant; I, intermediate resistant; S, susceptible. 
Antimicrobial susceptibility testing showed that $E$. faecalis isolated from dental calculus had low levels of resistance to ampicillin (13.9\%), vancomycin
$(4.6 \%)$, tetracycline $(11.6 \%)$, ciprofloxacin $(6.9 \%)$, and erythromycin $(13.9 \%)$.

Table 3. Association of enterococcus faecalis isolation with patients' underlying problems.

\begin{tabular}{|c|c|c|c|c|c|c|}
\hline E. faecalis & Dental infection & Gastrointestinal diseases & Endoscopy & Taking antibiotics & Filled teeth & Extracted teeth \\
\hline $\begin{array}{c}\text { Positive } \\
\text { (43 isolates) }\end{array}$ & $41(95.3 \%)$ & $8(18.6 \%)$ & $4(9.3 \%)$ & $11(25.6 \%)$ & $19(44.2 \%)$ & $37(86 \%)$ \\
\hline $\begin{array}{c}\text { negative } \\
\text { (164 isolates) }\end{array}$ & $160(97.6 \%)$ & $32(19.5 \%)$ & $29(17.8 \%)$ & $75(45.7 \%)$ & $83(50.6 \%)$ & $138(84.1 \%)$ \\
\hline
\end{tabular}

The prevalence of esp gene in our isolates was lower than other studies $(1,2,4,17-19)$, and that may be due to geographical differences or various clinical samples which were used in their studies. Moreover, the resistance rate to ampicillin, vancomycin, tetracycline, ciprofloxacin and erythromycin in our study had no significant correlation with the presence of esp gene. However, some studies have reported a high prevalence of this gene $(17,18)$. According to a study conducted from 2008 to 2010 in Iran (17), the prevalence of E. faecalis isolated from urinary tract infections was $73.4 \%$ while $47.1 \%$ of the isolates contained the esp gene. This difference in the prevalence of esp gene may be due to different samples used in the two studies. The abovementioned study (17) also showed that 64\%, 97\%, and $100 \%$ of their vancomycin-, ampicillin- and ciprofloxacin-resistant isolates contained the esp gene, while we did not find any correlation between them. However, the resistance rate to ampicillin in our study was higher than that of their isolates. These data show that the presence of esp gene may have a significant correlation with the resistance to these antibiotics in their study. However, the production of biofilm due to the presence of esp gene can facilitate the acquisition of some antibiotic resistance genes (17). Another study from Iran (18) has reported that $16.5 \%, 16.3 \%, 87.8 \%, 43.9 \%$ and $65.3 \%$ of their $E$. faecalis isolates were resistant to ampicillin, vancomycin, tetracycline, ciprofloxacin and erythromycin, respectively. However, $74.6 \%$ of their isolates contained the esp gene. This was probably due to different clinical samples used in their study. This difference in the prevalence of esp gene was in concordance with other studies conducted in Bulgaria and Brazil, which used various clinical samples (2, 18, 19). The high prevalence of E. faecalis encoding this gene in different areas may be dependent on the high prevalence of this organism in animals and human carriers, which can be as reservoirs of these bacteria.

The prevalence rate of esp gene in E. faecalis isolated from clinical and saliva/plaque samples collected in Germany (1), was $60 \%$ and $86.5 \%$, respectively.
Moreover, the prevalence rate of this gene in endodontic samples in the mentioned study was higher than that in our study (38.1\% vs. $18.6 \%)$.

E. faecalis is associated with various dental diseases and can lead to oral biofilm formation (1). The pathologic role of several virulence factors identified in E. faecalis is still under discussion and the function of these factors is unknown in the clinical isolates (1). A study carried out in Chile (20) investigated different clinical samples showed that the prevalence of esp gene in their E. faecalis isolated from urinary infection and bacteremia was $42 \%$ and $52 \%$, respectively, however this gene was not found in endodontic isolates. The results of these studies on $E$. faecalis indicate that the prevalence rate of this gene is different in various clinical samples. Current knowledge on the features of virulence factors in the pathogenesis of infections caused by this bacterium is still limited. The production of biofilm in this bacterium is dependent on multiple genes such as, $e p a, a t n, f s r, s r t \mathrm{~A}, s r t \mathrm{C}, e b p \mathrm{~A}, e b p \mathrm{~B}$, and $e b p \mathrm{C}$, suggesting that more comprehensive studies should be conducted on this subject.

\section{Conclusion}

The presence of esp gene is not the only cause of the acquisition of resistance genes due to biofilm formation. Antibiotic resistance is associated with several mechanisms of which the most important mechanism is to obtain the resistance genes from other bacteria present in the biofilm. Considering that none of the patients who were positive for esp in $E$. faecalis isolate used toothbrush, it is reasonable to expect that oral hygiene plays a major role in preventing biofilm formation.

\section{Acknowledgments}

Hereby, the authors would like to thank Mazandaran University of Medical Sciences for financial support and provision of required facilities to carry out the current project.

\section{References}

1. Anderson AC, Jonas D, Huber I, Karygianni L, Wölber J, Hellwig E, et al. Enterococcus faecalis from Food, clinical 
specimens, and oral sites: prevalence of virulence factors in association with biofilm formation. Frontiers in microbiology. 2016; 6:1534. PMID: 26793174

2. Strateva T, Atanasova D, Savov E, Petrova G, Mitov I. Incidence of virulence determinants in clinical Enterococcus faecalis and Enterococcus faecium isolates collected in Bulgaria. Brazilian Journal of Infectious Diseases. 2016; 20(2):127-33. PMID: 26849965

3. Banerjee T, Anupurba S. Prevalence of virulence factors and drug resistance in clinical isolates of Enterococci: A study from North India. Journal of pathogens. 2015; 2015. PMID: 26366302.

4. Alnasra NA, Badran EF, Dajan N, Shehabi AA. Antimicrobial susceptibility and virulence factors of Enterococci colonizing intestinal tract of infants. The International Arabic Journal of Antimicrobial Agents. 2016; 6

5. Kouidhi B, Zmantar T, Mahdouani K, Hentati H, Bakhrouf A Antibiotic resistance and adhesion properties of oral Enterococci associated to dental caries. BMC microbiology. 2011; 11(1):155. PMID: 21714920

6. Fallico L, Boldrin C, Grossato A, Franchin E, De Canale E, Tommasini T, et al. Molecular epidemiology of Enterococcus faecium isolates from an Italian hospital. Infection. 2011; 39(2):127-33. PMID: 21327628

7. Toledo-Arana A, Valle J, Solano C, Arrizubieta MaJ, Cucarella $\mathrm{C}$, Lamata $\mathrm{M}$, et al. The enterococcal surface protein, Esp, is involved in Enterococcus faecalis biofilm formation. Applied and environmental microbiology. 2001; 67(10):4538-45. PMID: 11571153 .

8. Wu H ,Moser C, Wang H-Z, Høiby N, Song Z-J. Strategies for combating bacterial biofilm infections. International journal of oral science. 2015; 7(1):1-7. PMID: 25504208

9. Frank KL, Vergidis P, Brinkman CL, Quaintance KEG, Barnes AM, Mandrekar JN, et al. Evaluation of the Enterococcus faecalis biofilm-associated virulence factors $\mathrm{AhrC}$ and Eep in rat foreign body osteomyelitis and in vitro biofilm-associated antimicrobial resistance. PloS one. 2015; 10(6):e0130187. PMID: 26076451

10. de la Fuente-Núñez C, Korolik V, Bains M, Nguyen U, Breidenstein EB, Horsman S, et al. Inhibition of bacterial biofilm formation and swarming motility by a small synthetic cationic peptide. Antimicrobial agents and chemotherapy. 2012; 56(5):2696-704. PMID: 22354291
11. Jhajharia K, Parolia A, Shetty KV, Mehta LK. Biofilm in endodontics: a review. Journal of International Society of Preventive \& Community Dentistry. 2015; 5(1):1. PMID: 25767760

12. Kim D, Sengupta A, Niepa TH, Lee B-H, Weljie A, FreitasBlanco VS, et al. Candida albicans stimulates Streptococcus mutans microcolony development via cross-kingdom biofilmderived metabolites. Scientific Reports. 2017; 7. PMID: 28134351

13. Tille P. Bailey \& Scott's Diagnostic Microbiology-E-Book: Elsevier Health Sciences; 2013.

14. Winn Washington C, Allen SD, Janda WM, Koneman EW, Procop GW, Schreckenberger PC, et al. Koneman's Color Atlas and Textbook of Diagnostic Microbiolgy: Lippincott, Williams \& Wilkins; 2006

15. Clinical and Laboratory Standards Institute. Performance standards for antimicrobial susceptibility testing: twenty-seven informational supplement. M100-S27, Wayne (PA); 2017

16. Leavis HL, Willems RJ, Top J, Spalburg E, Mascini EM, Fluit $\mathrm{AC}$, et al. Epidemic and nonepidemic multidrug-resistant Enterococcus faecium. Emerging infectious diseases. 2003; 9(9):1108. PMID: 14519248

17. Sharifi Y, Hasani A, Ghotaslou R ,Naghili B, Aghazadeh M, Milani $M$, et al. Virulence and antimicrobial resistance in enterococci isolated from urinary tract infections. Adv Pharm Bull. 2013; 3(1):197-201. PMID: 24312835

18. Kafil HS, Mobarez AM, Moghadam MF. Adhesion and virulence factor properties of Enterococci isolated from clinical samples in Iran. Indian Journal of Pathology and Microbiology. 2013; 56(3):238. PMID: 24152500

19. de Marques EB, Suzart S. Occurrence of virulence-associated genes in clinical Enterococcus faecalis strains isolated in Londrina, Brazil .Journal of medical microbiology. 2004; 53(11):1069-73. PMID: 15496382

20. Padilla C, Núñez M, Padilla A, Lobos O. Genes de virulencia y bacteriocinas en cepas de Enterococcus faecalis aisladas desde diferentes muestras clínicas en la Región del Maule, Chile. Revista chilena de infectología. 2012; 29(1):55-61. PMID: 22552513 